\title{
Microencapsulation of Lactic Acid Bacteria (LAB)
}

\author{
Andreas Feucht and Hae-Soo Kwak* \\ Department of Food Science and Technology, Sejong University, Seoul 143-747, Korea
}

\begin{abstract}
Lactic acid bacteria (LAB) are added to different food products for a long time due to health beneficial effects on human host. LAB is applied in dairy products, such as yoghurt, cheese, and various fermented products, and also in non-dairy products, such as sausages. However, reaching the human gut alive as well as in a sufficient cell amount to exert positive health effects is still a big challenge, due to LAB sensitive character and vulnerability against harsh and detrimental conditions in human digestive system. Keeping physiological activity of sensitive LAB strains alive is for the formulation of novel food products with a probiotic health claim of utmost interest, thus microencapsulation has been applied and investigated as a promising technique for a good and reliable protection. Microencapsulation allows reduced cell injury or cell loss by retaining cells within the encapsulating membrane and can be enforced by spray-drying, emulsion, extrusion, and a range of other technologies in combination with an appropriate coating material, such as alginate, chitosan, and mixture of these two polymers. In this review, established and well-studied microencapsulation techniques with their favored coating materials, as well as the recent applications of microencapsulated LAB into dairy products will be discussed.
\end{abstract}

Key words: microencapsulation, lactic acid bacteria, probiotics

\section{Introduction}

Probiotics are defined as "Live microorganisms which when administered in adequate amounts confer a health benefit on the host" (FAO/WHO, 2002) and include several microorganisms, mainly bacteria but yeasts as well. Regarding their health benefits, a minimum content of $10^{7}$ to $10^{9} \mathrm{CFU}$ of cell cultures per product portion is required to fulfill the general recommendation as a probiotic product in most countries (Ouwehand and Salminen, 1998).

Lactic acid bacteria (LAB), such as Lactobacillus acidophilus and Lactobacillus casei, are the longest applied organisms in the form of starter cultures and probiotics mainly in dairy (buttermilk, cheese, frozen desserts, acidophilus milk, yoghurt) as well as in non-dairy (chocolate, cereals, meat, juices) food products and play an important role by providing beneficial effects on the human gastro-intestinal (GI) tract (Baek and Lee, 2009; Burgain et al., 2011; Nazarro et al., 2012). The health benefits of $\mathrm{LAB}$ are mostly attributed to the fact that LAB produce lactic acid which can maintain the gut flora by keeping a

\footnotetext{
*Corresponding author: Hae-Sook Kwak, Department of Food Science and Technology, Sejong University, Seoul 143-747, Korea. Tel: 82-2-3408-3226, Fax: 82-2-3408-4319, E-mail: kwakhs@ sejong.ac.kr
}

low $\mathrm{pH}$ in the intestine (Parvez et al., 2006).

Several health benefits are attributed to LAB, such as their ability to prevent GI emerging diseases (anticarcinogenic properties), their usefulness in the treatment of disturbed intestinal microflora (antidiarrheal properties, antimicrobial activity) and increased gut permeability (reduction of fecal enzymes, improvement in lactose metabolism, enhancement of immune system res- ponse, improved bioavailability of nutrients) (Baek and Lee, 2009; Lee and Salminen, 1995). Furthermore, they are able to prevent colonization of several pathogens through antimicrobial mechanisms, so that it is of high priority to ensure a complete capsule release into the human gut in order to fulfill probiotic effects when LAB are administered in microencapsulated form (Naidu et al., 1999).

Free, unprotected LAB are exposed to several harsh conditions, such as high oxygen levels, manufacturing and freezing processes, storage of especially acid dairy products like yoghurt and transit through the human GI tract, so that microencapsulation can provide an efficient method to protect these sensitive orga- nisms (Krasaekoopt et al., 2003). Microencapsulation thus is certainly a quite suitable technique to overcome several challenges like a possible limited bioavailability due to presenting components in food system, color and/or taste change in product, but also degradation, oxidation, and activity loss 
of food-added ingredients (Schrooyen et al., 2001). Nevertheless food companies dealing with probiotics are still facing the difficulty to maintain cell viability over the storage time of food products, especially in such products where microencapsulated bacteria are exposed to high moisture conditions (Weinbreck et al., 2010). Therefore, this review focuses briefly and succinctly on some elected and prevalent microencapsulation techniques as well as commonly used encapsualtion materials and the current research of microencapsulated lactic acid bacteria applied into different foods.

\section{Microencapsulation of LAB}

Microencapsulation is defined as a technology to envelop small solid particles, liquid droplets or gases in a coating which forms microcapsules with a size between 1 and 1,000 $\mu \mathrm{m}$ (Nazzaro et al., 2012; Schrooyen et al., 2001). It is one of the most common methods to envelope probiotic organisms like LAB in order to improve their survival in food products during processing and storage as well as through GI tract passage (Goderska et al., 2003, Nazzaro et al., 2012). The number of viable cells reaching the gut is related to beneficial effects on the human host which can be exerted by probiotics. Del Piano et al. (2010) claimed that microencapsulation technique as a valid strategy to significantly improve gastroresistance of strains by enhancing their probiotic activity.

An older and similar technology presented the "Immobilized Cell Technology" (ICT) utilized in biotechnological areas, where LAB were microencapsulated for fermentation process in the dairy industry and outlined the origin and background of the present-day microencapsulation methods. Thus entrapment of LAB by ICT and its application into dairy products has been studied well and established for many years (Heidebach et al., 2012; Vidhyalakshmi et al., 2009). ICT has been mainly carried out to make homogeneous dispersion of the probiotic cells throughout the food products (Mortazavian et al., 2007). Nevertheless ICT can hardly fulfill the requirements of alternated environmental conditions, such as forming a strong physical barrier against low $\mathrm{pH}$ conditions in stomach and at the same time being digestible in human gut. The physical barrier is defined by the shell material of the capsule and has to control the mass transfer between core and outer phase (Desai and Park 2005; Kailasapathy, 2002; Lopez-Rubio et al., 2006). By this means, better protection of core material can be facilitated, because degradation factors, such as reactivity, water activ- ity, oxidation etc. can be reduced. The core materials i.e., the active cells are hereby embedded in a hydrogel which serves as a continuous matrix (Desai and Park, 2005).

Another important role is to release the cell from the capsules which allows to a certain degree of safe transportation into the gut. It is of utmost interest to keep the number of living cells stable by microencapsulation technology, since there is a long way until $\mathrm{LAB}$ will reach their final destination in human gut and exert their probiotic effects. On the same time, capsules should be formed in the size that doesn't have any adverse influence regarding sensorial aspects of food product (Heidebach et al., 2012). The size of microcapsules as well as the processing steps of generating small beads can have significant influences on the microcapsules yield (Capela et al., 2007). One alternative to overcome the problem of encapsulation yield loss during the production of small microcapsules is the application of rather protein based hydrocolloids than polysaccharide biopolymers in combination with an applied mild gelling technique (Chen et al., 2006).

\section{Microencapsulation Techniques}

Various methods, such as spraydrying, spraycooling, fluidized-bed coating, coextrusion, complex coacervation, solvent evaporation, interfacial and in situ polymerization have been studied, and applied as a microencapsulation technology (Anal and Singh, 2007; Kailasapathy, 2002; Mortazavian et al., 2007; Sanguansri and Augustin, 2010). Transforming bacterial cultures into concentrated dry powders were one of the first encapsulation technologies to improve the shelf-life of probiotics containing foods (Gbassi and Vandamme, 2012). These microencapsulation technologies are applied in combination with different food-grade polymers. The diameter of a microcapsule varies from a few microns to around $1 \mathrm{~mm}$ and consists of a semi-permeable, spherical, thin, and strong membrane which surrounds a solid or liquid core (Anal and Singh, 2007). Synonyms for microcapsules are microbeads, gel bead (if the capsule has a gel-like structure), and microsphere, since microbeads have usually a spherical to elliptical shape. Cracks in the surface of the beads are not unusual but an extension of these cracks leads to pore formation and can probably reduce encapsulation efficiency. Therefore, beads are commonly coated with asecond-layer (also known as coat, support or shell) to improve microencapsulation efficiency (Mortazavian et al., 2007).

Most reported literatures about microencapsulation of probiotic bacteria are based on small-scale laboratory 
procedures, involving the extrusion, emulsion or coacervation technique (Kailasapathy, 2002). Spray-drying technology is a new method developed in the recent time, also is a potential alternative to the common emulsion and extrusion technology. These methods vary in their physical, chemical and physico-chemical aspectswhen components,such as enzymes, volatile additives, polyphenols, natural ingredients, and bacteria (LAB) are incorporated into the capsules (Nazzaro et al., 2012; Sanguansri and Augustin, 2010). All methods have indeed varyingly strong influence on the viability of the cell culture, however, Kim et al. (1988) stated that no single processing steps like extrusion or drying step, etc. cause the loss of cell viability, but rather the storage of cell culture around room temperatures led to a significant cell loss.

\section{Spray drying technique}

In food industry, spray drying is a commonly applied encapsulation method producing large amounts of microcapsules in one continuous process step (Kailasapathy, 2002; Picot and Lacroix, 2004). This method is very suitable when microencapsulated probiotics need to be dried in order to allow storage over a long period. As illustrated in Fig. 1, the LAB containing solution - also called 'feed' - is given through a nozzle into the atomizer, where a mist is formed and consequently heat treated in the drying chamber. Hot gas runs through the drying chamber, therefore, it allows the evaporation of the solvent. Finally, the generated capsules are recovered by a cyclone separator.

Advantages of this technique are the possibility to en-
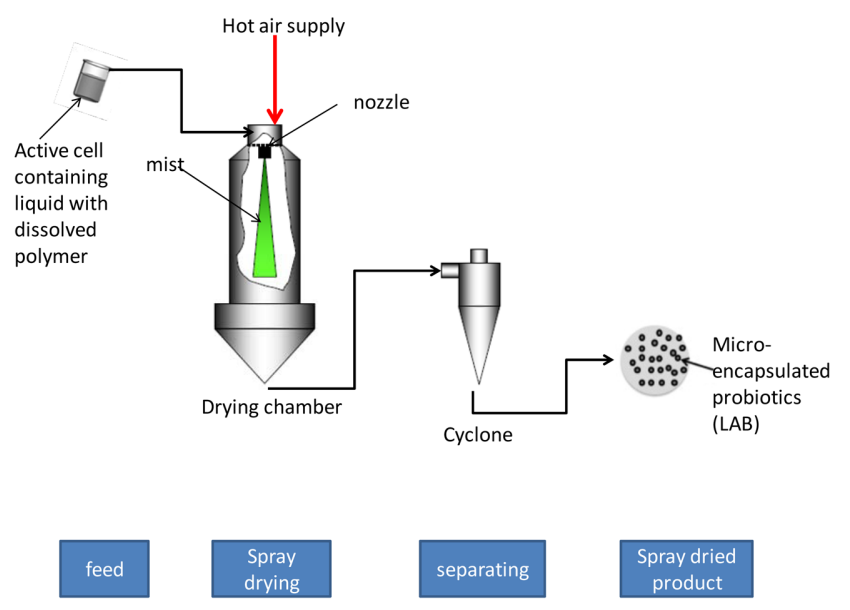

Fig. 1. Scheme of spray-drying procedure. The feed (active ingredient, here LAB containing solution) is given to the nozzle and then atomized to form a "mist" into the drying chamber. In the drying chamber blown hot gas allows evaporation of the solvent. Finally capsules are recovered by a cyclone separator (Modified from Bilancetti et al., 2010). force capsule-building and drying in one simple and continuous step, which allows a time-saving and therefore cost-reducing treatment with a shorten stress for the encapsulated microbial cells. By proper adjustment and control of the processing conditions, such as 'inlet and outlet' temperatures, viable encapsulated cultures of desired particle size distribution can be achieved (Kailasapathy, 2002). Besides the production of small size capsules at generally low costs, it has widespread application in the food sector by converting liquids into solid dry powders and a potential alternative to ICT based encapsulation methods (Heidebach et al., 2012).

An aqueous polymer, such as modified starch, whey protein isolate, gelatin etc. containing solution, makes the capsules hard enough to protect the LAB cells against harsh conditions, hereby serves as a base to form strong microcapsules (Heidebach et al., 2012). However, there are still difficulties during spray dying processes which have to be overcome. Mainly high temperatures which are used during the process are adverse to encapsulate heat sensitive LAB (Kailasapathy, 2002). Technological properties of LAB strains and in particular their heat resistance should be considered when applying these sensitive organisms for spray-drying encapsulation as well as during the spray-drying process applied inlet and outlet temperatures, which might have considerable impacts on the microencapsulation efficiency of microcapsules (Picot and Lacroix, 2004; Su et al., 2007). High temperature and osmotic pressure during the process are leading to dehydration of LAB which results in a significant living cell loss and reduced resistance against adverse effects due to damaged cell membranes (Meng et al., 2008). To overcome this drawback, a remedy can be provided by incorporating additive thermoprotectants prior to drying process which enhance the viability of cell culture (Anal and Singh, 2007).

\section{Emulsion technology}

Encapsulation by emulsion technique was developed in the early 1980's to immobilize sensitive living cells and is hence certainly one of the most applied methods to generate $\mathrm{LAB}$ containing microcapsules until today. This method can easily be scaled up and generate small beads with a diameter of around $25 \mu \mathrm{m}$ to $2 \mathrm{~mm}$. Compared with the extrusion method, the process costs might be higher since an organic phase, such as vegetable oil for the emulsion formation is indispensable (Mortazavian et al., 2007).

Referring to Fig. 2, the procedure consists of two simple steps, where in a first step the droplets are dispersed 


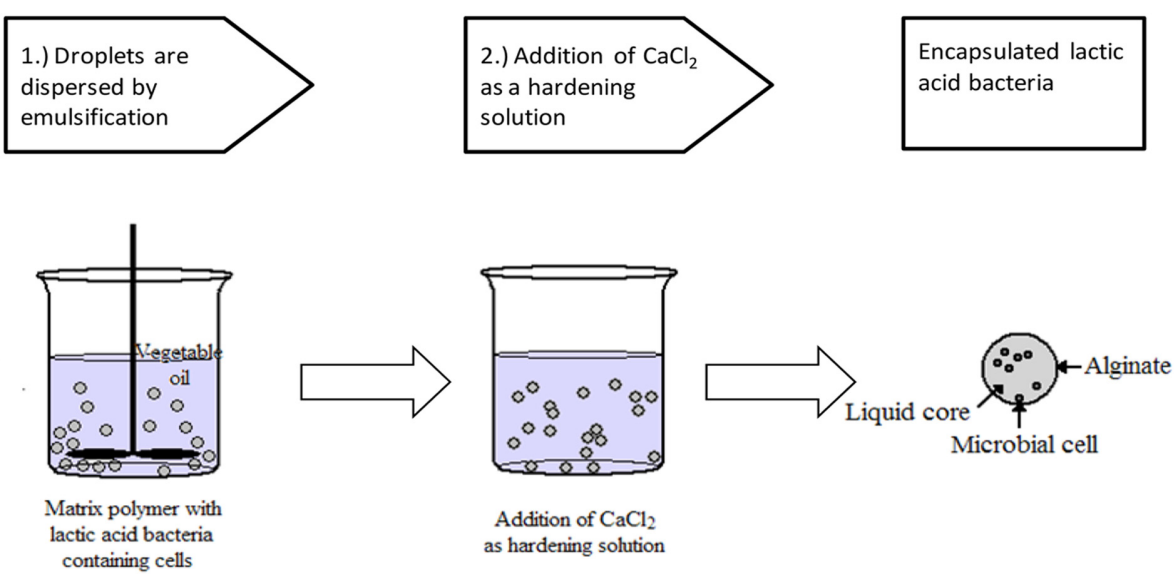

Fig. 2. Scheme of emulsion procedure. Into a large volume of vegetable oil (continuous phase) a small volume of the cell-polymer suspension (discontinuous phase) is added. The following homogenization step forms a water-in-oil emulsion. The water-in-oil emulsion is thereby formed and the water-soluble polymer must be insolubilised to form gel particles within the oil phase (Modified from Burgain et al., 2011).

by emulsification. This means that a continuous organic phase (e.g., vegetable oil) is given an aqueous hydrocolloid-cell-mixture (discontinuous phase) and emulsified, resulting in a water in oil emulsion (Kailasapathy, 2002). The following second step contains the addition of $\mathrm{CaCl}_{2}$ to harden the aqueous dispersion, so that small beads are then formed by insolubilizing the dispersed hydrocolloidcell-mixture within the oil phase (Krasaekoopt et al., 2003). Alternatively, a cooling process or addition of a gelling- or crosslinking agent can be applied to solidify the droplets (Kailasapathy, 2002).

As an emulsifier, Tween ${ }^{\circledR} 80$ (a polysorbate which is also known as polyoxyethylene sorbitan monooleate) at a concentration of $0.2 \%$, are frequently used for a better emulsion formation and by decreasing the interfacial tension of the water in oil phase, beads with a range of 25$35 \mu \mathrm{m}$ in diameter can be produced (Mortazavian et al., 2007; Scheu and Marshall, 1993). Three factors are essential to control the size of capsules, such as addition of emulsifiers, energy input (e.g., agitation rate) during emulsification and concentration, and viscosity ratio between continuous and dispersed phase before gelation (Heidebach et al., 2012; Truelstrup-Hansen et al., 2002). A high energy input is necessary to generate small beads, which can be achieved by using a homogenizer. The drawback of this device, however, is that the survival rate of living cells during homogenization process could be minimized, since it presents a mechanical and thermal stress, for LAB strains (Capela et al., 2007).

\section{Extrusion}

The extrusion technique, which is one of the oldest and most common techniques to produce hydrocolloid capsules, involves projecting a coating material and an emulsion core through a nozzle at high pressures. This method is also known as 'droplet method' and is able to increase the survival rate of probiotics up to $95 \%$ (Krasaekoopt et al., 2003).

Concentrated microorganisms are given into a hydrocolloid solution like sodium-alginate and subsequently extruded through the droplet forming nozzle as Fig. 3 illustrates. $\mathrm{A} \mathrm{CaCl}_{2}$ solution hereby serves as a hardening solution into which droplets are dropped. For the mass

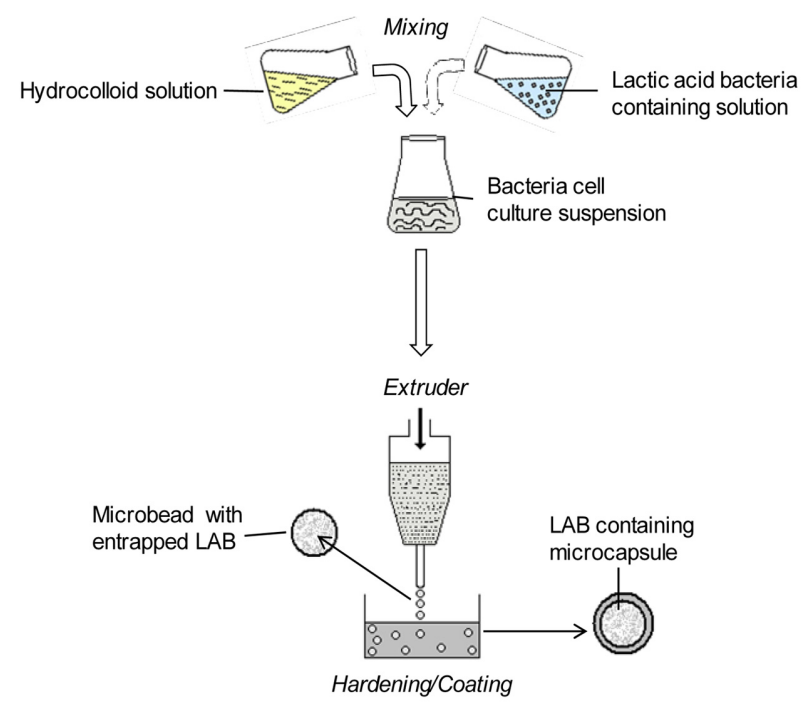

Fig. 3. Scheme of extrusion procedure. A hydrocolloid solution and $\mathrm{LAB}$ containing solution are mixed to form a cell suspension and consequently given to the extruder. Through a nozzle the cell suspension will be extruded forming droplets thereby which are directly dripping into a hardening solution (e.g., $\mathrm{CaCl}_{2}$ ). 
production of beads, various devices, such as centrifugal systems, jet cutting technique, multi-nozzle systems, and rotating disc atomizers are applied (Kailasapathy, 2002). This technology is a cheap, simple, and easy method with gentle treatment, so that cell injury can be kept minimal and provides relatively high viability of probiotics by retaining a high number of viable cells (Gbassi et al., 2012; Krasaekoopt et al., 2003; Mortazavian et al., 2007). In addition to that, extrusion technique is capable of producing more uniformly shaped microcapsules can be generated as compared with the emulsion technique (Nazzaro et al., 2012).

Several factors, such as hardening solution, viscosity of hydrocolloid-cell-mixture, and diameter of the orifice, determine the capsule size, which ranges between 0.3 and $3.0 \mathrm{~mm}$ in extrusion technique (Anal and Singh, 2007, Burgain et al., 2011). Regarding the encapsulation yield, the extrusion method is one of the most efficient techniques with almost $100 \%$ efficiency. However, living cell survival after spray-drying process is relatively low due to the detrimental conditions, such as heating and shear stress in this process (Urbanska et al., 2007).

Although extrusion method can only provide relatively large bead sizes, it is a frequently used technology to encapsulate LAB (Krasaekoopt et al., 2003). However, the biggest disadvantage is the fact that, this method can hardly be scaled up, because slow formation of microbeads is detrimental for large-scale production (Burgain et al., 2011; Mortazavian et al., 2007).

\section{Capsule Materials}

Several gel-forming biopolymers, such as alginate, guar, xanthan, locust bean, gellan, and carrageenan (gum), etc. as capsule materials for microencapsulation have been investigated and among them alginate, xanthan- and carrageenan gum seem to be the most suitable coating materials for a reliable protection of LAB (Lactobacillus acidophilus and Lactobacillus salivarius) under harsh conditions, such as acidic conditions and bile salts (Ding and Shah, 2009; Kailasapathy, 2002; Krasaekoopt et al., 2003).

Both alginate and carrageenan are derived from seaweed, so their similar capability to provide a high protection of viable cells is due to their same origin. Especially in cold acidic foods, such as yoghurt, alginate polymers are known to provide a higher survival and viability rate of probiotic bacteria (Adhikari et al., 2000; Picot and Lacroix, 2004; Shah and Ravula, 2000). An increased viability of microencapsulated cells can also be achieved by increasing the capsule size and gel concentration (Chandramouli et al., 2004). However, encapsulation of LAB into lipid-based encapsulation systems is not well studied and rather of low protective effect, so that lipid materials are in general less suitable for probiotic encapsulation.

Latest studies focus on breaking the mould by modifying the conventionally available polymers or by using an additional process step to improve the properties of the microcapsules. Novel polymeric microcapsules were created out of genipin crosslinked alginate-chitosan (GCAC) to encapsulate Lactobacillus plantarum, and an improved membrane strength and suppressed swelling of the capsule were the positive results (Chen et al., 2009). Chan and Zhang (2002) recommended a further compression coating technique as industrially potential (similar to the tablet compression) when the applied pressure is low enough to damage neither the cell wall nor its membrane. Improved cell viability in sodium alginate encapsulated Lactobacillus acidophilus could be observed.

\section{Alginate}

Alginate is a linear heteropolysaccharide derived from different algae types and mainly applied as a coating base in the microencapsulation technique due to its low cost, non-toxicity to human body and its advantages for technical application. Several scientists confirmed the efficacy of using alginate (also used as sodium or calcium alginate) as a microencapsulation material, enveloping probiotics in a safe surrounding shielded against outer impacts (Brusch-Brinques et al., 2011; Chandramouli et al., 2004; Kasra-Kermanshahi et al., 2010; Kim et al., 2008).

Alginate microcapsules have the advantage to be safe and non-toxic and can be applied as a protective delivery vehicle to administer safely viable bacteria to the intestine (Iyer et al., 2004; Iyer and Kailasapthy, 2005). LAB containing alginate capsules blended with starch is a common practice, since this method has proven an enhanced encapsulation effectiveness of these probiotic cells (Krasaekoopt et al., 2003). Lactobacillus gasseri encapsulated in alginate and coated with chitosan enhances the delivery of viable bacterial cells to the colon as well as survives under simulated intestinal and gastric conditions (Chávarri et al., 2010).

The effects of microencapsulation of Lactobacillus acidophilus by dropping method with sodium alginate on changes in survival rate under artificial gastrointestinal conditions were studied by Kim et al. (2008). Furthermore, they investigated the cholesterol assimilation and intestinal adhesion of this mentioned strain in order to 
explore the effect of microencapsulation on health benefits. A higher resistance to artificial intestine juice and heat treatment when cells are encapsulated with sodium alginate was observed (Kim et al., 2008).

In formulated products, the viability of probiotics was improved by ICT, applying sodium alginate beads which were processed with chitosan as an effective microencapsulation to maintain stability under storage at refrigeration temperature. A four times higher viability in yoghurt applied capsules compared to cells in a saline suspension was observed (Brusch-Brinques and Ayub, 2011). Also the microencapsulation of LAB Enterococcus faecium $\mathrm{MC} 13$ into alginate capsules with chitosan coating resulted in an improved delivery of viable cells as well as maintaining survival of these probiotic cells when exposed to adverse gastro-intestinal conditions (Kanmani et al., 2011).

\section{Chitosan}

Chitosan, a linear polysaccharide with negative charge due to its amine groups, derives from crustacean shells, insect cuticles and the membranes of fungi. It is the Ndeacetylated product of chitin as a biopolymer and it can form alginate, a gel structure by ionotropic gelation (Krasaekoopt et al., 2004; Mortazavian et al., 2007). Several of its properties, such as the unique polymeric cationic character, good biocompatibility, biodegradability, and nontoxicity make chitosan an important raw material in food and pharmaceutical area. Regarding its solubility, a complete release of this biomaterial is limited due to the fact that chitosan is water insoluble at $\mathrm{pH}$ higher than 5.4, and normally gut $\mathrm{pH}$ is higher than this value (Gbassi and Vandamme, 2012). Polyphosphates and sodium alginate are used as crosslinkers to allow a good stability of chitosan gel beads and microspheres (Anal and Singh, 2007). However, chitosan is rather used as a coat or shell than as a capsule base, since its efficiency for increased cell viability of probiotics is not satisfactory. Therefore, the microbeads containing solution with alginate capsules has to be dropped into a hardening chitosan- $\mathrm{CaCl}_{2}$ mixture in order to coat chitosan on alginate capsules (Mortazavian et al., 2007). Survival effects of the LAB strains $L$. acidophilus and $L$. casei, which were encapsulated in chitosan-coated alginate beads, were investigated in simulated digestive systems by Krasaekoopt et al. (2006) and the survival rate was observed to be higher in comparison to nonencapsulated cells.

L. bulgaricus KFRI 673 showed a better survival under simulated digestive systems and stability during storage at 4 and $22^{\circ} \mathrm{C}$ when encapsulated in high molecular weight chitosan-coated alginate particles. It therefore provided an effective possibility to deliver LAB to the colon and maintain their survival during refrigerated storage (Lee et al., 2004).

\section{Application of Microencapsulated LAB into Dairy Products}

\section{Yoghurt}

Different LAB strains have been microencapsulated to form various fermented food products (refer to Table 1), which are stored mainly at cool temperatures. Due to its general low probiotic activity, yoghurt is the most widely used basis supplemented with this kind of cell cultures (Shah, 2000). Adding encapsulated LAB can slower postacidification and also reduces acid development in yoghurt during storage. Overall sensory aspects in yoghurt do not substantially alter when encapsulated bacteria are incorporated, and survival of probiotics during storage can be improved by microencapsulation technique (Kailasapathy, 2006).

Using calcium alginate for the microencapsulation of probiotic bacteria in combination with prebiotics (e.g., Hi-Maize starch) in yoghurt, viability and survivability of encapsulated cells can be improved due to reduced acid production of LAB during storage (Sultana et al., 2000). Also Brusch-Brinques et al. (2011) stated the efficiency of microencapsulated probiotics into yoghurt resulting in an increased survival of Lactobacilli in yoghurt under refrigerated storage, but on the same time, there is a significant effect on sensorial attributes of the food product to detect. Graininess, for example, is associated with large capsule sizes, and flavor changes may be caused due to complex reactions between capsule hydrocolloids and yoghurt matrix (Heidebach et al., 2012). Therefore, Truelstrup-Hansen et al. (2002) recommended generally a microcapsule size below $100 \mu \mathrm{m}$ in order to avoid a negative sensorial impact of microcapsules in food.

\section{Cheese}

Bedside yoghurt, cheese is another microencapsulated LAB-supplemented dairy product. However, not all cheese types are suitable for adding microencapsulated cell cultures, because the physiological condition in a hydrocolloid matrix of alginate is not as favorable for the bacteria as a milk protein based rennet-gel-matrix (Godward and Kailasapathy, 2003; Heidebach et al., 2012). Addition of microencapsulated probiotic bacteria to Feta cheese can slow acid development during storage and increase water- 
Table 1. Application of encapsulated lactic acid bacteria in diverse food and dairy products (modified from Heidebach et al., 2012)

\begin{tabular}{|c|c|c|c|c|c|}
\hline $\begin{array}{l}\text { Encapsulated } \\
\text { strain* }\end{array}$ & $\begin{array}{c}\text { Matrix material and } \\
\text { encapsulation technique }\end{array}$ & $\begin{array}{l}\text { Average size } \\
\text { of capsules } \\
(\mu \mathrm{m})\end{array}$ & $\begin{array}{l}\text { Storage time } \\
\text { (and food matrix) }\end{array}$ & $\begin{array}{l}\text { Increased survival } \\
\text { due to micro- } \\
\text { encapsulation }\end{array}$ & Reference \\
\hline $\begin{array}{l}\text { Lactobacillus } \\
\text { bulgaricus }\end{array}$ & Alginate; emulsion & 15 (a) 30 (b) & $\begin{array}{l}2 \text { wk in frozen } \\
\text { ice-milk at }-18^{\circ} \mathrm{C}\end{array}$ & $\begin{array}{l}\text { No protective } \\
\text { effect for (a); } \\
\text { doubled survival } \\
\text { rate for (b) }\end{array}$ & $\begin{array}{c}\text { (Sheu et al., } \\
\text { 1993) }\end{array}$ \\
\hline $\begin{array}{l}\text { Lactobacillus } \\
\text { acidophilus }\end{array}$ & $\begin{array}{l}\text { Alginate, co-encapsulation with } \\
2 \% \text { resistant starch; emulsion }\end{array}$ & $500-1,000$ & $\begin{array}{c}8 \mathrm{wk} \\
\text { (in yoghurt) }\end{array}$ & $0.5 \log$ cycles & $\begin{array}{l}\text { (Sultana et al., } \\
\text { 2000) }\end{array}$ \\
\hline $\begin{array}{l}\text { Lactobacillus } \\
\text { acidophilus }\end{array}$ & Alginate; emulsion & not given & $\begin{array}{l}12 \text { wk in } \\
\text { fermented frozen } \\
\text { dairy dessert with } \\
\text { a pH of } 4.5 \text { at }-18^{\circ} \mathrm{C}\end{array}$ & 2-3 log cycles & $\begin{array}{c}\text { (Shah and } \\
\text { Ravula, 2000) }\end{array}$ \\
\hline $\begin{array}{l}\text { Two different strains } \\
\text { of Lactobacillus } \\
\text { acidophilus }\end{array}$ & $\begin{array}{c}\text { Alginate, co-encapsulation } \\
\text { with } 2 \% \text { resistant starch; } \\
\text { emulsion }\end{array}$ & $500-1,000$ & $\begin{array}{c}6 \text { mon } \\
\text { (in cheddar cheese) }\end{array}$ & $\begin{array}{l}\text { Higher cell } \\
\text { survival in samples } \\
\text { containing non- } \\
\text { encapsulated cells }\end{array}$ & $\begin{array}{l}\text { (Godward and } \\
\text { Kaliasapathy, } \\
\text { 2003) }\end{array}$ \\
\hline $\begin{array}{l}\text { Two strains of } \\
\text { Lactobacillus } \\
\text { acidophilus }\end{array}$ & $\begin{array}{l}\text { Alginate, co-encapsulation } \\
\text { with } 1 \% \text { resistant starch, } \\
\text { coated with chitosan; extrusion }\end{array}$ & $450-500$ & $\begin{array}{c}6 \mathrm{wk} \\
\text { (in yoghurt) }\end{array}$ & $\begin{array}{l}3 \log \text { cycles } \\
\text { for each strain }\end{array}$ & $\begin{array}{l}\text { (Iyer and } \\
\text { Kaliasapathy, } \\
\text { 2005) }\end{array}$ \\
\hline $\begin{array}{l}\text { Lactobacillus } \\
\text { acidophilus }\end{array}$ & $\begin{array}{c}\text { Alginate, co-encapsulation } \\
\text { with } 2 \% \text { resistant starch; } \\
\text { emulsion }\end{array}$ & not given & $\begin{array}{c}7 \text { wk } \\
\text { (in feta cheese) }\end{array}$ & $\begin{array}{l}\text { Higher cell } \\
\text { survival in samples } \\
\text { containing non- } \\
\text { encapsulated cells }\end{array}$ & $\begin{array}{l}\text { (Kaliasapathy } \\
\text { and Masondole, } \\
\text { 2005) }\end{array}$ \\
\hline $\begin{array}{c}\text { Lactobacillus } \\
\text { acidophilus and } \\
\text { Lactobacillus casei }\end{array}$ & $\begin{array}{l}\text { Alginate, coated with chitosan; } \\
\text { extrusion }\end{array}$ & 1,900 & $\begin{array}{c}4 \text { wk } \\
\text { (in yoghurt) }\end{array}$ & 1 log cycle & $\begin{array}{l}\text { (Krasaekoopt } \\
\text { et al., 2006) }\end{array}$ \\
\hline $\begin{array}{l}\text { Lactobacillus } \\
\text { acidophilus }\end{array}$ & $\begin{array}{l}\text { Alginate, co-encapsulation with } \\
1 \% \text { resistant starch; emulsion }\end{array}$ & $500-1,000$ & $\begin{array}{c}7 \mathrm{wk} \\
\text { (in yoghurt) }\end{array}$ & $2 \log$ cycles & $\begin{array}{l}\text { (Kaliasapathy, } \\
\text { 2006) }\end{array}$ \\
\hline $\begin{array}{l}\text { Lactobacillus } \\
\text { reuteri }\end{array}$ & $\begin{array}{l}\text { Alginate; emulsion (a) } \\
\text { Alginate; extrusion (b) }\end{array}$ & $\begin{array}{c}40(a) \\
2,000-3,000(b)\end{array}$ & $\begin{array}{l}27 \mathrm{~d} \text { in dry } \\
\text { fermented sausages }\end{array}$ & $\begin{array}{l}2 \log \text { cycles } \\
\text { for (a) and (b) }\end{array}$ & $\begin{array}{l}\text { (Muthukuma- } \\
\text { rasamy and } \\
\text { Holley, 2006) }\end{array}$ \\
\hline $\begin{array}{l}\text { Lactobacillus } \\
\text { casei }\end{array}$ & $\begin{array}{l}\text { Alginate, co-encapsulation with } \\
2 \% \text { resistant starch; emulsion }\end{array}$ & 18 & $\begin{array}{c}180 \mathrm{~d} \text { in } \\
\text { ice-cream at }-20^{\circ} \mathrm{C}\end{array}$ & $2 \log$ cycles & $\begin{array}{l}\text { (Homayouni } \\
\text { et al., 2008) }\end{array}$ \\
\hline $\begin{array}{l}\text { Lactobacillus } \\
\text { acidophilus }\end{array}$ & $\begin{array}{c}\text { Alginate; extrusion (a), } \\
\text { א-carrageenan; emulsion (b) }\end{array}$ & $\begin{array}{l}200-300(a) \\
300-400(b)\end{array}$ & $\begin{array}{l}\quad 90 \mathrm{~d} \text { in } \\
\text { white- brined cheese }\end{array}$ & $\begin{array}{l}2 \log \text { cycles } \\
\text { for (a) and (b) }\end{array}$ & $\begin{array}{l}\text { (Ozer et al., } \\
\text { 2009) }\end{array}$ \\
\hline
\end{tabular}

*If not stated otherwise, lactic acid bacteria strains were separately microencapsulated.

holding capacity of the cheese, due to open texture of cheese, possible disintegration of microcapsules in brine solution and a higher salt uptake during incorporation, microencapsulated probiotic bacteria cannot be protected well (Kailasapathy and Masondole, 2005).

Microencapsulation of L. acidophilus into white-brined cheese might be able to induce formation of acetaldehyde and diacetyl as well as increasing the concentration of long-chain FFAs on the one hand, on the other hand survival and cell viability of probiotics is improved to a satisfactory count, so that the final product can be claimed as a probiotic cheese. Regarding sensorial aspects, overall acceptability and other parameters were not deteriorated by microencapsulation (Özer et al., 2009).

\section{Frozen dairy products}

There is only a small amount of other dairy products into which microencapsulated LAB are added. This is mainly because of different food matrices which are not all appropriate in the same way to protect LAB containing microcapsules. The cell amount of LAB in frozen fermented dairy desserts and frozen yoghurt is significantly reduced due to detrimental effects caused by oxygen toxicity, acid, sugar concentration, and freezing injury (Shah, 2000). Nevertheless, microencapsulation technique can be also applied to enhance cell viability in products, such as ice cream and fermented frozen dairy desserts, which has in general a high potential as a food carrier for probiotic bacteria and might support greater cell viability especially during storage at very low temperatures. By entrapping Lactobacilli in calcium alginate an about $40 \%$ higher survival rate of these microorganisms during freezing ice milk could be achieved in comparison with non-trapped probiotic cells (Scheu and Marshall, 1993). However, se- 
veral detrimental factors caused by different stresses which are leading to viability loss of bacteria during product formulation, processing, storage, and melting have to be overcome (Mohammadi et al., 2011). The larger the beads in frozen dairy the more it will influence the texture with coarseness, on the other side the smaller the beads the worse the protection of bacteria (Khosrokhavar and Mortazavian, 2010).

However, Homayouni et al. (2008) achieved in a synbiotic ice cream, where resistant starch was applied as a prebiotic compound a $30 \%$ higher survival rate of calcium alginate encapsulated LAB ( $L$. casei) at defined storage period and time without any significant effects on sensory properties.

\section{Non-dairy products}

Also in other food products LAB has been added under different conditions. The yoghurt-like tasting Kou Woan Lao, an oriental-style dairy product coagulated by microcapsules containing probiotics and filtrates from fermented rice was developed and the microencapsulated $L$. acidophilus BCRC 14079 and culture filtrates from laochao resulted in good protection for the milk-clotting enzymes and LAB ( $\mathrm{Su}$ et al., 2007). Microencapsulation technology was also used to protect $L$. reuteri from harsh environment during sausage processing (Muthukumarasamy and Holley, 2006). Without altering any sensory quality of the sausage, a certain level of probiotic organisms was maintained in the final product at consumption by microencapsulation of $L$. reuteri into alginate beads. By this means $L$. reuteri might be an option for formulation of fermented meat products providing health-promoting viable bacteria (Muthukumarasamy and Holley, 2006).

\section{Conclusion}

There are numerous lactic acid bacteria strains with own individual properties and consequently behavior interacting with its surrounding, so that further studies and research regarding this aspect should be enforced in the near future. Microencapsulation is a valuable process technology to facilitate the addition of ingredients especially of probiotics in the form of LAB and bifidobacteria into food, but will them also make more expensive and independently, and bioavailability should be of main focus at any time. Not only dairy products but also more and more other foods, such as meat products, soy and cereal based products, vegetables, and fruits, could be potential carriers for microencapsulated LAB in future. Research should be also focused on further opportunities of microencapsulated LAB obtaining additional benefits by putting them into different food products.

\section{Acknowledgements}

This study was supported by a grant from Small and Medium Business Administration in Seoul, Republic of Korea and a scholarship from GIZ (Gesellschaft fur Internationale Zusammenarbeit) in Bonn, Germany.

\section{References}

1. Adhikari, K., Mustapha, A., Grün, I. U., and Fernando, L. (2000) Viability of microencapsulated bifidobacteria in set yogurt during refrigerated storage. J. Dairy Sci. 83, 19461951.

2. Anal, A. K. and Singh, H. (2007) Recent advances in microencapsulation of probiotics for industrial applications and targeted delivery. Trends Food Sci. Tech. 18, 240-251.

3. Baek, Y. J. and Lee, B. H. (2009) Probiotics and prebiotics as bioactive components in dairy products. In: Bioactive Components in Milk and Dairy Products. Park, Y. W. (ed) WileyBlackwell, Ames, pp. 287-310.

4. Bilancetti, L., Poncelet, D., Loisel, C., Mazzitelli, S., and Nastruzzi, C. (2010) A statistical approach to optimize the spray drying of starch particles: Application to dry powder coating. AAPS Pharma. Sci. Tech. 11, 1257-1267.

5. Brusch-Brinques, G. and Ayub, M. A. Z. (2011) Effect of microencapsulation on survival of Lactobacillus plantarum in simulated gastrointestinal conditions, refrigeration and yogurt. J. Food Eng. 103, 123-128.

6. Burgain, J., Gaiani, C., Linder, M., and Scher, J. (2011) Encapsulation of probiotic living cells: From laboratory scale to industrial applications. J. Food Eng. 104, 467-483.

7. Capela, P., Hay, T. K. C., and Shah, N. P. (2007) Effect of homogenization on bead size and survival of encapsulated probiotics bacteria. Food Res. Int. 40, 1261-1269.

8. Chan, E. S. and Zhang, Z. (2002) Encapsulation of probiotic bacteria Lactobacillus acidophilus by direct compression. Food Bioprod. Process. 80, 78-82.

9. Chandramouli, V., Kaliasapathy, K., Peiris, P., and Jones, M. (2004) An improved method of microencapsulation and its evaluation to protect Lactobacillus spp. in simulated gastric conditions. J. Microbiol. Meth. 56, 27-35.

10. Chávarri, M., Marañón, I., Ares, R., Ibáñez, F. C., Marzo, F., and del Carmen Villarán, M. (2010) Microencapsulation of a probiotic and prebiotic in alginate-chitosan capsules improves survival in simulated gastro-intestinal conditions. Int. J. Food Microbiol. 142, 185-189.

11. Chen, H., Ouyang, W., Martoni, C., and Prakash, S. (2009) Genipin cross-linked polymeric alginate-chitosan microcapsules for oral delivery: In-vitro analysis. Int. J. Polym. Sci. 2009, 1-16.

12. Chen, L. Y., Remondetto, G. E., and Subirade, M. (2006) Food 
protein-based materials as nutraceutical delivery systems. Trends Food Sci. Tech. 17, 272-283.

13. Del Piano, M., Carmagnola, S., Andorno, S., Pagliarulo, M., Tari, R., Mogna, L., Strozzi, G. P., Sforza, F., and Capurso, L. (2010) Evaluation of the intestinal colonization by microencapsulated probiotic bacteria in comparison with the same uncoated strains. J. Clin. Gastroenterol. 44, 42-46.

14. Desai, K. G. H. and Park, H. J. (2005) Recent developments in microencapsulation of food ingredients. Dry. Technol. 23, 1361-1394.

15. Ding, W. K. and Shah, N. P. (2009) Effect of various encapsulating materials on the stability of probiotic bacteria. J. Food Sci. 74, 100-107.

16. FAO/WHO (2002) Food and Agriculture Organization of the United Nations/World Health Organization. Guidelines for the evaluation of probiotics in food. London, Ontario, Canada. April 30 and May 1, 2002.

17. Gbassi, G. K. and Vandamme, T. (2012) Probiotic encapsulation technology: From microencapsulation to release into the gut. Pharm. 4, 149-163.

18. Goderska, K., Zybala, M., and Czarnecki, Z. (2003) Characterisation of microencapsulated Lactobacillus Rhamnosus LR7 Strain. Pol. J. Food Nutr. Sci. 12/53, 21-24.

19. Godward, G. and Kalilasapathy, K. (2003) Viability and survival of free, encapsulated and co-encapsulated probiotic bacteria in yoghurt. Milchwissenschaft 58, 161-164.

20. Heidebach, T., Först, P., and Kulozik, U. (2012) Microencapsulation of probiotic cells for food applications. Crit. Rev. Food Sci. Nutr. 52, 291-311.

21. Homayouni, A., Azizi, A., Ehsani, M. R., Yarmand, M. S., and Razavi, S. H. (2008) Effect of microencapsulation and resistant starch on the probiotic survival and sensory properties of symbiotic ice cream. Food Chem. 111, 50-55.

22. Iyer, C. and Kailasapathy, K. (2005) Effect of co-encapsulation of probiotics with prebiotics on increasing the viability of encapsulated bacteria under in vitro acidic and bile salt conditions and in yogurt. J. Food Sci. 70, 18-23.

23. Iyer, C., Kailasapathy, K., and Peiris, P. (2004) Evaluation of survival and release of encapsulated bacteria in ex vivo porcine gastrointestinal contents using a green fluorescent protein gene-labelled E. coli. Lebensm. Wiss. Technol. 37, 639642.

24. Kailasapathy, K. (2002) Microencapsulation of probiotic bacteria: Technology and potential applications. Horizon Scientific Press. Curr. Iss. Intest. Microbiol. 3, 39-48.

25. Kailasapathy, K. and Masondole, L. (2005) Survival of free and microencapsulated Lactobacillus acidophilus and Bifidobacterium lactis and their effect on texture of Feta cheese. Aust. J. Dairy Tech. 60, 252-258.

26. Kailasapathy, K. (2006) Survival of free and encapsulated probiotic bacteria and their effect on the sensory properties of yoghurt. LWT 39, 1221-1227.

27. Kanmani, P., Satish-Kumar, R., Yuvaraj, N., Paari, K. A., Pattukumar, V., and Arul, V. (2011) Effect of cryopreservation and microencapsulation of lactic acid bacterium Enterococcus faecium MC13 for long-term storage. Biochem. Eng. J. 58-59, 140-147.
28. Kasra-Kermanshahi, R., Fooladi, J., and Peymanfar, S. (2010) Isolation and microencapsulation of Lactobacillus spp. from corn silage for probiotic application. Iran. J. Microbiol. 2, 98102.

29. Khosrokhavar, R. and Mortazavian, A. M. (2010) Effects of probiotic containing microencapsules on viscosity, phase separation and sensory attributes of drink based on fermented milk. Milchwissenschaft 65, 177-179.

30. Kim, H. S., Kamara, B. J., Good, I. C., and Enders G. L. (1988) Method for the preparation of stabile microencapsulated lactic acid bacteria. J. Ind. Microbiol. 3, 253-257.

31. Kim, S. J., Cho, S. Y., Kim, S. H., Song, O. J., Shin, I. S., Cha, D. S., and Park, H. J. (2008) Effect of microencapsulation on viability and other characteristics in Lactobacillus acidophilus ATCC 43121. LWT 41, 493-500.

32. Krasaekoopt, W., Bhandari, B., and Deeth H. (2003) Evaluation of encapsulation techniques of probiotics for yoghurt. Int. Dairy J. 13, 3-13.

33. Krasaekoopt, W., Bhandari, B., and Deeth, H. C. (2006). Survival of probiotics encapsulated in chitosan-coated alginate beads in yoghurt from UHT- and conventionally treated milk during storage. LWT-Food Sci. Technol. 39, 177-183.

34. Lee, J. S., Cha, D. S., and Park, H. J. (2004) Survival of freezedried Lactobacillus bulgaricus KFRI 673 in chitosan-coated calcium alginate microparticles. J. Agr. Food. Chem. 52, 73007305.

35. Lee, Y. K. and Salminen, S. (1995) The coming of age of probiotics. Trends Food Sci. Technol. 6, 241-245.

36. Lopez-Rubio, A., Gavara, R., and Lagaron J. M. (2006) Bioactive packaging: Turning foods into healthier foods through biomaterials. Trends Food Sci. Technol. 17, 567-575.

37. Meng, X. C., Stanton, C., Fitzgerald, G. F., Daly, C., and Ross, R. P. (2008) An hydrobiotics: The challenges of drying probiotic cultures. Food Chem. 106, 1406-1416.

38. Mohammadi, R., Mortazavian, A. M., Khosrokhavar, R., and Gomes da Cruz, A. (2011) Probiotic ice cream: Viability of probiotic bacteria and sensory properties. Ann. Microbiol. 61, 411-424.

39. Mortazavian, A., Razavi, S. H., Ehsani, M. R., and Sohrabvandi, S. (2007). Principles and methods of microencapsulation of probiotic microorganisms. Iranian J. Biotechnol. 5, 118.

40. Muthukumarasamy, P. and Holley, R. A. (2006) Microbiological and sensory quality of dry fermented sausages containing alginate-microencapsulated Lactobacillus reuteri. Int. J. Food Microbiol. 111, 164-169.

41. Naidu, A. S., Bidlack, W. R., and Clemens, R. A. (1999) Probiotic spectra of lactic acid bacteria (LAB). Crit. Rev. Food Sci. Nutr. 39, 13-126.

42. Nazzaro, F., Orlando, P., Fratianni, F., and Coppola, R. (2012) Microencapsulation in food science and biotechnology. Curr. Opin. Biotechnol. 23, 182-186.

43. Özer, B., Kirmaci, H. A., Şenel, E., Atamer, M., and Hayaloğ lu, A. (2009) Improving the viability of Bifidobacterium bifidumBB-12 and Lactobacillus acidophilus LA-5 in whitebrined cheese by microencapsulation. Int. Dairy J. 19, 22-29.

44. Ouwehand, A. C. and Salminen, S. J. (1998) The health ef- 
fects of cultured milk products with viable and non-viable bacteria. Int. Dairy J. 8, 749-758.

45. Parvez, S., Malik, K. A., Kang, S. A., and Kim, H. Y. (2006) Probiotics and their fermented food products are beneficial for health. J. Appl. Microbiol. 100, 1171-1185.

46. Picot, A. and Lacroix, C. (2004) Encapsulation of bifidobacteria in whey protein-based microcapsules and survival in simulated gastrointestinal conditions and in yoghurt. Int. Dairy J. 14, 505-515.

47. Sanguansri, L. and Ann Augustin, M. (2010) Microencapsulation in functional food product development. In: Functional food product development. Smith, J. and Charter, E. (eds) Wiley-Blackwell, Oxford, UK, pp. 1-23.

48. Schrooyen, P. M. M., van der Meer, R., and de Kruif, C. G. (2001) Microencapsulation: Its application in nutrition. P. Nutr. Soc. 60, 475-479.

49. Shah, N. P. (2000) Probiotic Bacteria: Selective enumeration and survival in dairy foods. J. Dairy Sci. 83, 894-907.

50. Shah, N. P. and Ravula, R. R. (2000) Microencapsulation of probiotic bacteria and their survival in frozen fermented dairy desserts. Aust. J. Dairy Tech. 55, 139-144.

51. Sheu, T. Y. and Marshall, R. T. (1993) Microentrapment of Lactobacilli in calcium alginate gels. J. Food Sci. 58, 557-561.

52. Su, L. C., Lin, C. W., and Chen, M. J. (2007) Development of an oriental-style dairy product coagulated by microcapsules containing probiotics and filtrates from fermented rice. Int. J. Dairy Tech. 60, 49-54.

53. Sultana, K., Godward, G., Reynolds, N., Arumugaswamy, R., Peiris, P., and Kailasapathy, K. (2000) Encapsulation of probiotic bacteria with alginate-starch and evaluation of survival in simulated gastrointestinal conditions and in yoghurt. Int. J. Food Microbiol. 62, 47-55.

54. Truelstrup-Hansen, L., Allan-Wojtas, P. M., Jin, Y. L., and Paulson A. T. (2002) Survival of Ca-alginate microencapsulated Bifidobacterium spp. in milk and simulated gastrointestinal conditions. Food Microbiol. 19, 35-45.

55. Urbanska, A. M., Bhathena, J., and Prakash, S. (2007) Live encapsulated Lactobacillus acidophilus cells in yoghurt for therapeutic oral delivery: Preparation and in vitro analysis of alginate-chitosan microcapsules. Can. J. Physiol. Pharmacol. 85, 884-893.

56. Vidhyalakshmi, R., Bhakyaraj, R., and Subhasree, R. S. (2009) Encapsulation "The future of probiotics" - a review. Adv. Biol. Res. 3, 96-103.

57. Weinbreck, F., Bodnár, I., and Marco, M. L. (2010) Can encapsulation lengthen the shelf-life of probiotic bacteria in dry products. Int. J. Food Microbiol. 136, 364-367.

(Received 2012.9.7/Revised 2013.4.3/Accepted 2013.4.5) 